Cad.Est.Ling., Campinas, 47(1) e (2):17-18, 2005

\title{
LEMBRANÇAS DO PROJETO
}

\author{
MARIA CECÍLIA PERRONI \\ (IEL, Universidade Estadual de Campinas)
}

Impossibilitada de estar presente, com os colegas, neste dia comemorativo da criação de nosso Projeto em Aquisição da Linguagem no Departamento de Lingüística, gostaria de dirigir a nossa tão querida coordenadora original, Cláudia Lemos, uma pequena mensagem de saudação.

Fazia calor e não chovia em Campinas, naquele fevereiro de 1976. Ao sair do carro, Cláudia deixou cair uma carteira e alguns papéis. Recém chegada da fria e úmida Escócia, quão penosa deve ter sido sua readaptação a sua terra natal! Na Unicamp, um pequeno grupo de estudantes, alguns já interessados em Aquisição da Linguagem, aguardava ansiosamente por um líder, alguém que viesse a nos orientar e desenvolver essa área de estudos linguísticos em nosso país. Mas o que não poderíamos ter previsto àquela altura, era a imensa habilidade, entusiasmo, carisma e dedicação com que seríamos presenteados através de Cláudia. Se essa pesquisadora nata perdeu a carteira naquele dia, logo ganhou uma legião de admiradores entre seus novos alunos, no primeiro Projeto de Aquisição da Linguagem por ela criado. Como participante do mesmo, nunca poderia me esquecer dos percalços e dificuldades enfrentados naqueles tempos épicos de desbravação do imenso sertão de nossa ingenuidade como alunos e pesquisadores. Não havia computadores: o projeto original, enviado à Fapesp em 1976, foi datilografado por mim numa velha Olivetti manual. Não havia gravadores: excluindo-se os portáteis particulares, os primeiros adquiridos foram os de rolo... hoje peças de museu! Mas, havia Cláudia Lemos e seu otimismo e imensa capacidade, liderando uma verdadeira batalha diária com gravações, orientações, aquisição de bilbiografia e suas aulas, cada vez mais concorridas. O projeto cresceu rápido e deu seus frutos, como todos sabem. A certa altura, fomos carinhosamente apelidadas, por um colega do DL., de "psicofrenéticas", no que tinha razão. E parodiando a velha canção das "cantoras do rádio", eu cantarolava pelos corredores do Iel: "Nós somos as psicofrenéticas Vivemos a vida a gravar. De dia gravamos crianças, De noite transcrevemos sem parar."

Estes últimos 25 anos se passaram muito depressa, foram muitas as conquistas, talvez tantas quanto as dificuldades enfrentadas. $\mathrm{O}$ balanço é extremamente positivo, e dentre tantas idas e vindas, a título de recordação (e provocação...), gostaria de perguntar às colegas: 
PERRONI - Lembranças do projeto

- Fausta - "Você já terminou as gravações da Verrô?"

- Rosa - "Você sabe quem está com o gravador?"

- Cláudia - "Quem vai gravar os gêmeos amanhã?"

- Ester - "Você me empresta suas transcrições do Tiago?"

A caminhada foi longa, limito-me hoje a pinçar apenas algumas cenas de nossa jornada no Projeto, com imensa alegria por todos nós, com muito orgulho por ter tido a oportunidade de contribuir com algumas linhas nessa bela página da história do DL e do IEL. Para finalizar, gostaria de enviar a nossa orientadora de ontem e de sempre, à Cláudia, a Cuca, a "Códa bandeira nacional", meus cumprimentos por tantos frutos já colhidos, na certeza de que muitos outros virão.

Parabéns, Cláudia!

Um grande abraço, da Cecília 